Library Trends, Vol. 55, No. 3, 2007, p.442-453.

ISSN: (Electronic: 1559-0682) (Print: 0024-2594)

http://www.press.jhu.edu/journals/library trends/

http://muse.jhu.edu/journals/library_trends/v055/55.3greenberg.pdf

(C) 2007 The Board of Trustees, University of Illinois

\title{
The Paris Commune of 1871 and the Bibliothèque Nationale
}

\author{
Gerald S. Greenberg
}

\begin{abstract}
During the Paris Commune of 1871, communards assumed responsibility for administration of the Bibliothèque Nationale. On April 1 the Commune appointed Citizen Jules Vincent the library's supervisor. Three weeks later, the Commune dismissed Vincent when it discovered that he had embezzled 10,000 francs that had been allocated to meet library expenses. Vincent's behavior had immense consequences for the Commune. This article will examine how Versailles attempted to portray Vincent's action as symbolic of communard deceit; how it became virtually impossible for the Commune to regain the trust of library managers and employees; and how Elie Reclus, a widely respected humanitarian and academic, was faced with the challenging task of managing the library and protecting its collection during the final five weeks of the Commune's existence.
\end{abstract}

\section{Background}

At the conclusion of the Franco-Prussian War in September 1870, France was forced to sign a humiliating treaty with Prussia. Faced with this national disgrace, Paris watched in anger as voters proceeded to elect a government with a distinctly monarchist agenda. In response, the Parisian working class and National Guard rose in rebellion, calling for the commune to govern the city. The rise of the commune was quickly associated with violent memories of the French Revolution (1789-95) and the Revolution of 1848.

The Paris Commune of 1871 may have been the first great uprising of the proletariat against bourgeois exploitation, as Karl Marx maintained. While this interpretation of events is generally granted some validity, many historians believe the principal cause of the rebellion to be the unpopular and provocative actions of France's newly elected monarchist assembly, whose reactionary agenda served to unify diverse opposition forces in Paris, most of which could not be legitimately characterized as socialist in the modern sense of the word. Many French nationalists, already offended by the humiliating treaty that had just concluded the Franco-Prussian War, and still suffering from the long wartime siege, now watched as Adolphe Thiers (1797-1877), France's newly elected chief executive, proceeded to lead the rural-dominated assembly in passing legislation anathema to most Parisians: cessation of the wartime moratorium on debts and rents, termination of further wage payments to the National Guard, and relocation of the national capital from Paris to Versailles. This combination of factors resulted in a broad-based Parisian rising that established the Commune on March 26, 1871.

The Bibliothèque Nationale had been closed since September 15, 1870, two weeks after the collapse of the French Army at Sedan, where Emperor Napoleon III and 100,000 of his men had been captured by the Prussians. When news of this disaster reached Paris on September 4, angry crowds swept aside imperial authority and proclaimed a republic. Long-suffering Parisians, besieged and fearful, may have taken hope from this bloodless revolution, but the atmosphere was one of chaos and apprehension. Library officials, under the direction of Jules 
Taschereau, sought to safeguard the collection. During October they packed the volumes into unmarked boxes and evacuated them (Dubief, 1961, p.31). It was not until the Treaty of Frankfurt was signed on March 1 that serious thought was given to reassembling the library with an eye toward reopening its doors to visitors. On March 3 library workers began this process. No longer threatened by violent Prussian incursion, Taschereau and the other library administrators did not regard the potential for internal strife as reason enough to keep the Bibliothèque Nationale closed any longer.

Fifteen days later, Taschereau had a change of heart. Paris had risen in rebellion against what they regarded as an unjust peace treaty and the new monarchist government in Versailles. Taschereau had good reason to fear for his safety for he had aided the police in their actions against the communards of 1848 (Dubief, 1961, p. 31), some of whom, like Auguste Blanqui (1805-81), were still prime movers of Parisian radicalism. Accordingly, Taschereau left for Versailles shortly after March 18, delegating administration of the library to Henri Delaborde (1811-99), curator of engraving ("The national library under the commune" 1871; Dubief, 1961, p. 31). Delaborde's first few weeks as administrator were uneventful. Taschereau's departure did not spur a general exodus of library personnel, and the Bibliothèque Nationale continued to prepare for reopening as scheduled.

On March 26 Paris's rebel leaders proclaimed the Commune. At first this event passed virtually unnoticed at the library. As might easily be imagined, administration of the Bibliothèque Nationale was hardly a priority of the communards. For eight days the library had gone about its business on its own, and it would enjoy this freedom for almost another week. A similar situation prevailed at the Louvre, where personnel considered themselves a free corporation for eighteen days until the Commune named artist Gustave Courbet (1819-77) superintendent on April 13 (Barbet de Jouy, 1898, p. 197). Louvre administrator J. Henri Barbet de Jouy experienced numerous conflicts with Courbet over the issues of democratic selection of administrators by artists, provision of office space for new artist/administrators, and requisitioning of funds for administration of the museum (Barbet de Jouy, 1898, pp. 198-204). At one point, Barbet de Jouy was told that his position no longer existed and that he should either resign or stand for election. Despite these clashes, compromise with Courbet proved possible, and Barbet de Jouy still considered the Louvre employees to be effectively in charge. The Commune, Barbet de Jouy mused, might even be viewed as having been protective of the museum, keeping it closed during threatening times and reopening it only when the artists' federation was able to provide for its safe operation (Barbet de Jouy, 1898, p. 200).

\section{Jules Vincent}

On April 1, 1871, the Commune placed Citizen Jules Vincent in charge of the Bibliothèque Nationale. The announcement of this appointment, issued by the Commune's Committee of the Interior and General Safety, was signed by Frédéric Cournet (1839-85), Emile Oudet (1825-?), and Théophile Ferré (1845-71). Its stated purpose was to guarantee the conservation of France's past scientific glory for future generations (Journal officiel, 1872, p. 175). The unstated political purpose was to prevent the library from functioning as a center of counterrevolution under the leadership of library officials Léopold Delisle and Charles-Aimè Dauban, ${ }^{1}$ both regarded by the Commune as reactionaries (Dommanget, 1930, p. 14). Under the direction of Vincent, it was expected that library employees would take all appropriate measures to safeguard the collection and continue to discharge their duties under the Commune's 
leadership. This staff included Jules Ravenel (1801-85), curator of imprints; O. S. Barbris and E. J. B. Rathery (1807-75), associate curators of imprints; Henri Delaborde, curator of engravings; Charles-Aimè Dauban (1820-76), curator and associate director of the Department of Engravings, Anatole Chabouillet (1814-99), curator and associate director of the Department of Medallions and Antiques; H. Lacroix (1814-99), curator and adjunct associate director of the Department of Medallions and Antiques; ${ }^{2}$ Léopold Delisle (1826-1910), librarian of the Department of Manuscripts; ${ }^{3}$ and librarians H. Baudement, Eugène Nuitre, Georges Duplessis, J. Guerin, and one Schmidt.

By all accounts, the collections at both the Bibliothèque Nationale and the Louvre were well protected during the period of the Commune despite numerous claims to the contrary issued by the government at Versailles. The appointment of Vincent at the Bibliothèque Nationale and the appointment of Courbet at the Louvre were political acts, aimed at guarding against possible counterrevolution. Both institutions were to be reorganized in the communard image with governance performed by committees of workers. Versailles's false charges of vandalism represented the opposition's political reply.

Vincent's tenure at the Bibliothèque Nationale was destined to be a brief one, but its repercussions would prove to be a formidable obstacle for communard aspirations of reform. It is not clear how Jules Vincent came to be selected for his post. Nothing that is known of his background would suggest his promotion to such a position. Born in 1827, he was a gunsmith by profession. In 1860 he was convicted of fraud, a fact that was apparently not known to the Commune's leadership at the time. ${ }^{4}$ His arrival at the library, however, did not cause immediate problems. Delaborde, acting head since Taschereau's departure almost two weeks before, had the good sense to accept the reality of the situation. While not acknowledging Vincent's legal right to the directorship, he was willing to establish a pragmatic relationship that would enable the library's work to continue under existing conditions ("The national library under the commune," 1871). Vincent appeared satisfied with this situation and promised not to interfere in the library's operation (Dubief, 1961, p. 32). The Commune also decided to extend library employees exemption from service in the National Guard in order that they might continue their work uninterrupted (Journal officiel, 1872, p. 339). This exemption had been in effect throughout the Prussian siege of Paris. On April 22 Vincent announced that the library would reopen on the 24th (Journal officiel, 1872, p. 339). There is some question, however, whether Vincent played any part in the decision to reopen. This may well have been decided at a meeting of curators several days earlier (Dubief, 1961, p. 33) and, given the hands-off working relationship that had been established between Vincent and library personnel, seems plausible.

Vincent's stewardship of the Bibliothèque Nationale was abruptly terminated on April 27 due to an apparent misappropriation of Commune funds (Journal official, 1872, p. 412) Although not officially reported until May 4, it appears that Vincent withdrew a total of 30,000 francs from the Commune's Department of Finance and deposited only 20,000 with the library's accountant, P. Boisard. ${ }^{5}$ This personal appropriation of library funds appears to have amounted to one eighth of all money provided to the library during the period March 20-April $30 .^{6}$

Vincent attempted to explain the financial shortfall by contending that several library employees refused to accept the money that he was attempting to dispense to them. While it appears that at least some library staff chose to forego payment rather than create the impression that they were accepting the legitimacy of the Commune's authority, this hardly justifies the fact that 10,000 francs remained in Vincent's possession. Curator Dauban was among those still intensely loyal to Versailles, and he was also instrumental in bringing charges against Vincent (Dubief, 1961, p. 
33; Dauban, 1873, pp. 153-54). Perhaps it is debatable whether Vincent's behavior was the result of dishonesty or ineptitude because the event was never properly investigated. Given Vincent's previous conviction for fraud, however, one is easily led to believe that history was repeating itself. Certainly, the Commune needed to immediately disassociate itself from Vincent's behavior. Vincent's actions served to validate all the worst suspicions of the Commune's enemies: the rebellious Parisians were little more than common criminals, their stated ideals mere cover for their mercenary schemes. Paris papers printed false reports that Vincent had stolen valuable artwork from the library ("The national library under the commune," 1871). Versailles's charges now seemed credible to many. The question facing the Commune was whether it was possible to repair the damage. They would attempt to do so on April 29 by appointing as Vincent's successor noted scholar and scientist Elie Reclus (Journal official, 1872, p. 421). Named inspector of communal libraries and installed at the Bibliothèque Mazarine (Bourgin, 1907, p. 112) was journalist Benjamin Gastineau (1823-1903), destined to be the only communard library official to be captured and sentenced after the Commune's fall. ${ }^{7}$

\section{Integrity and Reform}

At the same time that Jules Vincent was apparently embezzling funds from the Bibliothèque Nationale, the Louvre was being reorganized according to communard principles. Now the library would face the same challenges. Elie Reclus (1827-1904), the library's new director, was both a social reformer and a scholar, as was his brother Elisée (1830-1905). Trained for a career in theology, Elie Reclus studied at Geneva and Strassbourg, receiving his Doctor of Divinity degree in 1851. Three years earlier, however, he became a utopian socialist, greatly influenced by the ideas of Charles Fourier (1772-1837). After the fall of the Commune, Elie Reclus became recognized as a seminal anthropologist breaking new ground in an emerging academic discipline with his studies of primitive peoples (Ellis, 1927). Staff at the Bibliothèque Nationale, however, had not expected that a man of Reclus's stature would work to advance the ideals of the Commune. They regarded him as a turncoat. ${ }^{8}$

Both Vincent's dismissal and Reclus's appointment were accomplished by Edouard Vaillant (1840-1915), education delegate and member of the Commune's executive body. Vaillant had been trained as an engineer and studied medicine before devoting himself full-time to social revolution. A friend and follower of Blanqui, Vaillant often played the role of communard compromiser, attempting to mediate disputes between the extremist neo-Jacobins and the more moderate socialists. He was also vocal in his opposition to the killing of Versailles hostages, and in the last week of the Commune's existence he joined with war delegate and Committee of Public Safety member Louis Delecluze in an attempt to negotiate peace with the Prussians. Nevertheless, Vaillant's devotion to the cause of social revolution cannot be questioned. As education delegate, he ordered the complete expulsion of clergy from Paris schools. ${ }^{9}$

Reclus's reception at the Bibliothèque Nationale was reflective of the staff's attitude toward the Commune following their experience with Vincent. Upon arrival, he found the doors to his office bolted and needed the assistance of a locksmith to gain admittance. ${ }^{10}$ In addition, Taschereau's nephew and library official Guèrin made his implacable opposition to the new director apparent from the start (Dubief, 1961, p. 35). Reclus attempted to treat all employees fairly, but his appointment of heraldry scholar Joannis Guigard as associate director ${ }^{11}$ exacerbated matters. Guigard was a former employee of the library. He had been dismissed, 
however, due to his public attacks against library administration. It has been suggested that perhaps even more repugnant to library personnel was the fact that Guigard was very

knowledgeable concerning the value of the monographic collection, and staff feared his ability to identify any precious volumes being appropriated for private use ("The national library under the commune," 1871).

At least one journalist commented that invasion of churches had been common during historical periods of social upheaval, but invasion of a literary temple was more of a shock (Dubief, 1961, p. 36). Despite this rare incursion, no books were lost, nor were any works of art at the Louvre sold despite frequent journalistic charges to the contrary. ${ }^{12}$ Reclus's faith in the National Guard to protect the library's holdings proved well placed, despite the soldiers' general unfamiliarity with the material charged to their care. Had any books been lost, the communards and their cause would have been quickly discredited by their detractors. A journalist at the British Daily News cited the safeguarding of the library's monographic collection as a greater accomplishment than protection of the Louvre's holdings because it was much easier to dispose of books following theft than it was paintings ("The national library under the commune," 1871). The measures that Reclus took to protect the library's collection also addressed the question of internal security. As Elie's brother characterized a problem common to many a research library, "more than one illustrious savant was at the same time a book thief" (Reclus, 1927). The situation was described by one historian as "pillage of the public libraries by the privileged" (Dommanget, 1930, p. 15). In order to prevent material from leaving the library in any manner, Reclus at the Bibliothèque Nationale and Gastineau at the Mazarine, suspended all library loans (Bourgin, 1907, p. 112). Heightened security, of course, is readily viewed as distrust, and Reclus's measures served to increase the tension existing between administration and staff.

On May 9 Reclus and Guigard resolved to exercise their authority in an attempt to establish a more orderly and disciplined workforce at the library. They announced that library employees would be required to sign an attendance sheet when reporting to work (Dubief, 1961). The librarians, led by Delisle, maintained that this demand violated the operational freedom granted to them when the Commune appointed Vincent on April 6 (Journal official, 1872, p. 175). While Vincent's mandate makes no mention of altering existing library routines or procedures, it is clear that Reclus was authorized by the Commune to make more sweeping changes (Journal official, 1872, p. 531). The library staff's recalcitrance now prompted Reclus to formally demand their allegiance to the Commune on May 11. The staff responded by circulating a petition declaring the Versailles government to be the only one deserving of their recognition (Dubief, 1961, p. 37; “The national library under the commune," 1871). The confrontation had now escalated to the point that a working relationship between staff and administration was no longer possible. Consequently, Reclus proceeded to dismiss most of the staff, including Delisle. ${ }^{13}$ The stated basis for dismissal was absenteeism, evidence of which was supplied by the unsigned attendance sheets.

Had attendance documentation and allegiance to the Commune not been issues, Delisle would probably still have been discharged by Reclus because the manuscript librarian was firm in his belief that Reclus had no authority to make any substantive changes in library policy or personnel. This was especially true, Delisle maintained, when the issue was replacement of bibliographic specialists. By May 11 Reclus and Delisle were embroiled in yet another controversy stemming from Reclus's decision to install Egyptian bibliographer Anys el Bittar as curator of manuscripts. Delisle's candidate for the job was Jules Simon, Versailles's minister of public education (Dubief, 1961, p. 38). Simon demurred, citing other priorities. There was no 
question that Bittar was qualified for his position, but Delisle insisted that his candidate, Simon, in his ministerial capacity, was the only man with authority to make personnel changes at the library. Delisle made it clear that he would refuse to accept Bittar's installation as curator of manuscripts on May 12. This, Delisle believed, was the real reason for his dismissal.

In actuality, the issues of attendance, allegiance, and personnel change all center around the refusal of library staff to accept the authority of the Commune. Most were supporters of Versailles from the beginning, and their experience with Jules Vincent served to confirm them in their anti-communard stance. Perhaps Reclus could have proceeded more slowly in his efforts to reform library culture, but, as events would subsequently demonstrate, time was a precious commodity. Surely Delisle realized that Reclus and Vaillant would not consider granting Jules Simon an administrative role at the library, even had Simon been willing to accept one. Simon, a conservative republican and future prime minister (1876-77), had been influential in preventing continued resistance to Prussia after the fall of Paris in January 1871 by forcing the resignation of Léon Gambetta (1838-82), who wanted to continue resistance from Bourdeaux. By accepting a post offered by Thiers in the Versailles government, Simon solidified his position as an enemy of the Commune.

Most of the librarians who were dismissed by Reclus on May 11 returned to the library the next day, having obtained admission as patrons ("The national library under the commune," 1871, p. 6). With most of the library's staff now occupying reading space in the public area, Reclus found himself in need of workers. He wrote to Vaillant, expressing his intention to begin hiring replacement staff immediately (Dubief, 1961, p. 39). Within one day, however, Reclus decided that reinstating most of the staff was a more practical option. It was not even required that the returning workers declare their allegiance to the Commune. Consequently, twenty-five of the old employees returned to service, joining six new staff that included Anys el Bittar and author/archivist Robert Halt. ${ }^{14}$

The reinstated workers still were hostile to Reclus, but did the director consider them a personal threat to his safety? Apparently dismissed curator Dauban believed so. He reported locating a message, sent by Reclus to Vaillant, asking for firearms to be delivered to the Bibliothèque Nationale for use by himself and Guigard (Dauban, 1873, p. 308). In the message Reclus states that he believes the dismissal of the library employees might result in an armed attack. The note is dated May 15, and the signature of "Reus" is only partially legible. Is it possible that the recent tension at the library caused Reclus to view former members of the staff now squatting in the reading room as a likely source of violence? There is no evidence to this effect. In addition, one must consider that Dauban's animosity toward the Commune rivaled Delisle's, and he cannot be considered an impartial chronicler of events. For these reasons one is not convinced of the note's authenticity. ${ }^{15}$

It would be a mistake to characterize all librarians at the Bibliothèque Nationale as Versailles loyalists. At least two dismissed librarians, Baudement ${ }^{16}$ and Cheron, were good Republicans (Dubief, 1961, p. 40), but they were united with their colleagues in opposition to the communard administration. While most of the dismissed library staff returned to work, some did not. A few of the returning librarians decided to take up residence in the library, and they did not leave the building again until it was reclaimed by Versailles troops ("The national library under the commune," 1871). Reclus found himself short on manpower (particularly loyal manpower) and funding. He had great plans to democratize library culture, but had neither the means nor the time to accomplish them. He allocated whatever funding Vaillant was able to provide him for maintenance of the library and its staff. This selflessness was appreciated by at least a few library 
personnel (Dubief, 1961, p. 40), but it did not compensate for the general hostility that he faced.

\section{What Might Have Been}

Reclus believed that the library should play a prominent role in the democratization of society. He shared Vaillant's vision of a society where education was free and secular. Toward this end, he was determined to launch a public lecture program that would bring the masses into the library. Attendees would be inspired by educational messages delivered by socially progressive speakers. Reclus consulted with bibliophile Paul Lacroix, ${ }^{17}$ literary critic Jules Troubat, ${ }^{18}$ and Egyptologists Prisse d'Avesnes ${ }^{19}$ and Marchandon de la Faye. ${ }^{20}$ He hoped to enlist the assistance of professors at l'Ecole des Chartres. This new vision of the library corresponded with Reclus's ideal of a democratized society, one he shared with friend and advisor Aristide Rey, a disciple of anarchist Mikhail Bakunin (1814-76). Reclus also dreamed of replacing library administrator Delaborde with artist and republican soldier Adrien Tournachon (1825-1903).

Many of the individuals with whom Reclus conferred were strongly influenced by Charles-Augustin Sainte-Beuve (1804-69), the man who revolutionized French literary criticism by severing the academic discipline from partisanship and prejudice (Lehmann, 1962). He accomplished this largely through the rise of French newspapers such as Le Moniteur (17891868) and Le Temps (1861-1900) that published his critical articles. Their popular reception guaranteed that Sainte-Beuve's essays, pioneering exercises in biographical and historical criticism, would continue to appear in a relatively independent forum. It was not, however, Sainte-Beuve's portraits of great writers that influenced social progressives but rather his liberal ideas on public issues. After his appointment to the Senate in 1865, he championed public libraries, ${ }^{21}$ freedom of thought, and education, and it was these ideals that most impressed Reclus and his circle of advisors. Admirable though they were, it is questionable whether these social and educational goals could have ever been realized under the Commune given the direction that Paris's leadership chose to take as their confrontation with Versailles progressed. In its final weeks the Commune took a more violent turn toward neo-Jacobinism, one that frightened even Jules Troubat and Robert Halt, Reclus's associates who were closest to the communards (Dubief, 1961, p. 42). Even had there been time, the political atmosphere was not one within which new freedoms were likely to flourish.

\section{The End}

As late as May 20, readers continued to occupy the long tables of the Bibliothèque Nationale (Lissagaray, 1876, p. 236). Two days later the Commune's experiment in library administration came to an end when the library closed its doors. The Versailles Army was quickly approaching, and the primary concern was the safety of the facility and its collection. Fortunately, the library did not occupy a position of strategic importance to the battle of Paris. The library was not even defended when Versailles troops arrived on May 23 ("The national library under the commune," 1871). As a result, the structure and its holdings were spared the ensuing destruction that was visited upon much of the city. Reclus, unable to reach the library on May 23, took refuge in the Bercy section of Paris (Reclus, 2000, p. 159). From there he escaped through Italy to Zurich. Of all the Commune's library administrators only Gastineau was captured by the forces of Versailles. He was condemned to deportation and imprisonment. 
Reclus, Guigard, and the other library officials were condemned in absentia for insurrection, not the seemingly more appropriate offense of usurpation of government functions. Reclus and many others eventually returned to France following issuance of a general amnesty on July 10, 1880.

It has been said that "the Commune was a barricade, not a government" (Lissagaray, 1876, p.194-195). Its attempts to govern were characterized by an excess of liberty. Debate raged constantly and endlessly in the Commune's governing bodies. Denied freedom for so long, the communards would not place restraints upon it now that they had power. There was an inability to act quickly and decisively in a time of crisis, a crucial lack of money, and in the end, very little time. The funding problem might have been remedied in the short run had the Commune decided to seize the banks, but funding was not the crucial issue at the Bibliothèque Nationale_ - time was. Reclus's plans needed more than three weeks for realization. He was handicapped further by the animosity of the library staff, a sentiment born of loyalty to Versailles but fed by Vincent's dismal administration. The Commune should be credited with providing protection for the library's collection. That the Bibliothèque Nationale escaped the fire that consumed much of Paris in the Commune's last days must be attributed to the fact that its location was not of strategic importance to the combatants. Perhaps Reclus and Vaillant might consider their goal of democratization of library culture to have been at least partially realized by the emergence and growth of public libraries and the evolution of societies that are more responsive to the needs of their citizens. Progress in these areas, however, when achieved, has required decades of hard labor to establish and protect, and it cannot be said that the work is ever completed.

\section{Notes}

1. Dauban was the author of Le fond de la société sous la commune (1873).

2. For more information on Anatole-Chabouillet and Lacroix, see Bibliothèque Nationale de France (2005).

3. Delisle published a four-volume history of the National Library's manuscript collection (Delisle, 1881), after having assumed dictatorship of the entire library in 1874. During his tenure, which lasted until 1905, the library's card catalog was completed. For further biographic/bibliographic details see http://www.dictionaryofarthistorians.org/. Delisle's entry is found at http://dictionaryofarthistorians.org/delislel.htm.

4. Dubief (1961, p. 34) estimates that the Commune discovered Vincent's criminal record about the time of his dismissal, and it may represent the actual reason for his termination.

5. Vincent's withdrawal is reflected in a financial report published in the Journal officiel (1872, p. 466); library accountant Boisard's note stating the discrepancy between funding earmarked for the library and the amount he actually received is published in Journal officiel (1872, p. 522).

6. Lissagaray (1876, p. 176), The French journalist Lissagaray (1838-1901) was a Commune participant who spent the first five years of his exile writing this memoir. It was first published in Brussels in 1876. The first English version was published ten years later. Karl Marx's daughter Eleanor was the translator.

7. Lissagaray mentions Gastineau's appointment (1876, p. 185) but places him at the Bibliothèque Nationale; Dubief notes his condemnation and deportation (1961, p. 43). Gastineau published the 1870s newspaper Le trombinoscope under the pen name Touchatout.

8. Dubief (1961, p. 35). Elie Reclus's brother Elisée, later a noted geographer, was captured by Versailles forces during combat at Châtillon. His death sentence was commuted to perpetual banishment after European scientists appealed on his behalf. He was an inmate at fourteen different prisons. According to Lissigaray, he succeeded in opening a school with a small library at Quérlern for the facility's 151 prisoners. After operating for a short period of time, it was closed by Jules Simon, minister of public education (Lissigaray, 1876, p. 324). A third brother, Paul, joined Elie and Elisée in action at both the September 4 and March 18 Paris uprisings. The brothers published manifestos and journals in support of the republic. Elie was wounded in one hand during the violence. After serving in the National Guard, he was transcribing and classifying papers at the Tuileries and working as a social worker in the 5th arrondissement when named library director.

9. Vaillant's contributions to the Commune are detailed extensively throughout Frank Jellinek's The Paris Commune 
of 1871 (Jellnik, 1965, pp. 154, 225, 226, 291, 292, 296, 308, 353, 404). After the fall of the Commune, Vaillant fled to Britain. He was sentenced to death in absentia. In England he secured a lectureship at London University and became an intimate of Karl Marx. He returned to France in 1880 after the government withdrew the death sentence and was elected to the National Assembly in 1893. A brief biography can be found at http://www.spartacus.schoolnet.co.uk/FRvaillant.htm.

10. Similarly, Barbet de Jouy (1898, p. 200) would not even give Courbet a room at the Louvre until the Commune forced him to compromise.

11. The appointment was officially confirmed on May 6 (Journal officiel, 1872, p. 482).

12. Barbet de Jouy $(1898$, p. 202) refuted such allegations as pure fabrication.

13. Journal officiel (1872, p. 531). The Journal officiel lists twenty-four names besides Delisle: Aumoitte, d'Auriac, Bellifent, Bertal, Bréhant, Chabouillet, Chéron, Claude, Cortambert père, Cortambert (Richard), Courajod, Depping, Frank, Julien (Stanislas), Klein, Lacabane, Lavoix fils, Marchal, Nöel ( J.), Paris (Paulin), Rousseaux, Soury, ThierryPoux, and Zottemberg (a specialist in oriental manuscripts). The Daily News reported that a total of sixty-five employees were dismissed.

14. Halt, author of Papiers sauvés des Tuileries suite à la correspondance de la famille impériale (1871), was a member of a commission charged with collecting, classifying, and publishing the papers of the Tuileries.

15. Dubief (1961, note 40) considered the text a forgery.

16. He was the subject of an autobiography (1875) by Julien Travers (1802-1888).

17. Lacroix (1807-84) known as "le bibliophile Jacob," was a scholarly writer, editor, and bibliographer.

18. Troubat (1836-1914) was secretary to literary historian Charles Sainte-Beuve and executor of his estate.

19. Achille-Constant-Theodore Emile Prisse d'Avesnes (1807-79) was a writer, engineer, linguist, and humanitarian who embraced Islam and spent his life meticulously studying and documenting the historic and artistic contributions of ancient Egypt and medieval Islam. See Mary Norton (1990).

20. He was co-author with Prisse d'Avesnes of Histoire de l'art Ėgyptien d'après les monument (1878).

21. From 1840 to 1848 Sainte-Beuve was employed at the French Institute's Mazarine Library.

\section{References}

Barbet de Jouy, J. (1898). Journal de Barbet de Jouy pendant la commune. (1898). Le Revue Hebdomaire, 10, 198204.

Bibliothèque Nationale de France. (2005) Les directeurs du department des monnaies, médailles et antiques depuis 1719. Retrieved March 24, 2006, from http://www.bnf.fr/PAGES/ connaitr/pdf/directeurs_medailles.pdf.

Bourgin, G. (1907). Histoire de la commune. Paris: E. Cornély.

Dauban, C. A. (1873). Le fond de la société sous la commune. Paris: E. Plon.

Delisle, L. (1881). Le cabinet des manuscrits de la bibliothèque impériale. 4 vols. Paris: Imprimerie Impériale.

Dommanget, M. (1930). L'instruction publique sous la commune. Paris: Internationale des travailleurs de l'enseignement Paris.

Dubief, H. (1961). L'administration de la bibliothèque nationale pendant la commune. Le Mouvement Sociale 37, 31-43.

Ellis, Havelock. (1927). Elie Reclus. In Ishill, J. (Ed.), Elisée and Elie Reclus: In memorium. Berkeley Heights, NJ: Oriole Press. Retrieved March 20, 2006, from http://recollectionbooks. .com/bleed/Encyclopedia/ReclusElisee/ishill46-50.

Halt, R. (1871). Papiers sauvés des Tuileries suite à la correspondence de la famille impériale. Paris: E. Dentu.

Jellinek, F. (1965). The Paris commune of 1871. New York: Grosset and Dunlap.

Journal officiel de la république française sous la commune. (1872). Réimpression, Paris: V. Bunel.

Lehmann, A. G. (1962). Saint-Beuve: A portrait of the critic, 1804-1832. Oxford: Clarendon Press.

Lissagaray, P. (1876). History of the Paris Commune of 1871. London: New Park.

The national library under the commune. (1871, June 23). London Daily News, pp. 5-6.

Norton, M. (1990). Prisse: A portrait. Saudi aramco world. Retrieved March 20, 2006, from http://www.saudiaramcoworld.com/issue/199006/prisse-a.portrait.htm.

Prisse d'Avesnes, A., \& de la Faye, M. (1878). Histoire de l'art Égyptien d'après les monuments. Paris: A. Bertrand.

Reclus, Elie. (2000). La Commune de Paris au jour le jour 19 mars-28 mai 1871. Paris: Seguier.

Reclus, Elisée. (1927). Elie Reclus (1827-1904). In Ishill, J. (Ed.). Elisée and Elie Reclus: In memorium. Berkeley Heights, NJ: Oriole Press. Retrieved March 20, 2006, from http:

//recollectionbooks.com/bleed/Encyclopedia/ReclusElisee/ishill240-258.html.

Travers, J. (1875). Baudement de la bibliothèque nationale. Caen: Imprimerie de la F. le Blanc-Hardel. 